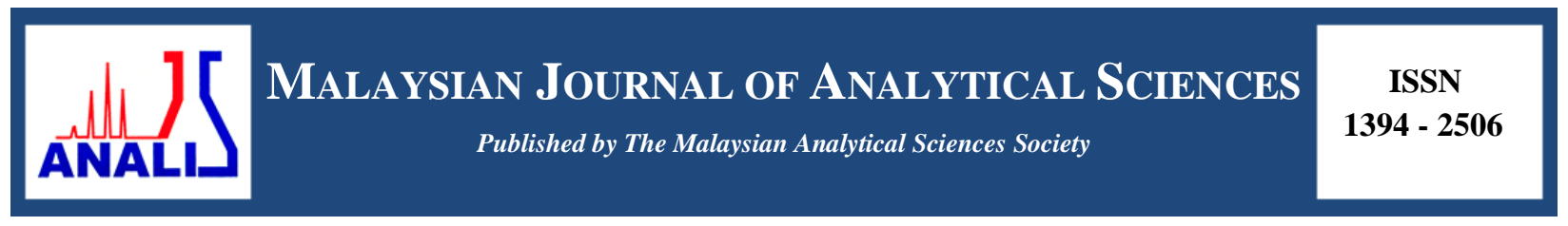

\title{
THE USE OF LOW GRADE LIMESTONE IN ACID MINE DRAINAGE TREATMENT
}

\author{
(Penggunaan Batu Kapur Bergred Rendah dalam Rawatan Saliran Lombong Berasid) \\ Anuar Othman ${ }^{1,2}$, Azli Sulaiman ${ }^{1 *}$, Ismail Ibrahim ${ }^{2}$ \\ ${ }^{1}$ Department of Chemistry, Faculty of Science \\ Universiti Teknologi Malaysia, 81310 Johor Bahru, Johor, Malaysia \\ ${ }^{2}$ Mineral Research Centre, \\ Department of Mineral and Geoscience Malaysia, 31400 Ipoh, Perak, Malaysia \\ *Corresponding author: azli@kimia.fs.utm.my
}

Received: 25 October 2017; Accepted: 22 January 2019

\begin{abstract}
In this study, low grade limestone (LGL) was used in treating acid mine drainage (AMD). Based on X-ray fluorescence (XRF) result, the content of calcium carbonate mineral in limestone used was around $80 \%$ that can be considered as LGL. The $\mathrm{pH}$ of AMD samples increased after treated with all parameter weights of LGL at every five minutes of interval times. The parameters weights of LGL used in the experiments were 1.0, 2.0, 3.0, 4.0, 5.0 and $6.0 \mathrm{~g}$. For every parameter weight of LGL, the interval times used were $0,5,15,20,25$ and 30 minutes. The highest of $\mathrm{pH}$ value obtained was $6.44 \pm 0.00$ by using $6.0 \mathrm{~g}$ of LGL at interval time 30 minutes. The suitable $\mathrm{pH}$ value chosen was $6.11 \pm 0.00$ by using $5.0 \mathrm{~g}$ of LGL at interval time 20 minutes because the parameter had complied with Standards A and B of Environmental Quality Act 1974 with less cost compared to other parameters. Heavy metals content such as arsenic, cadmium, chromium, iron, manganese and zinc had decreased after reaction with all LGL weights. The content of arsenic in AMD samples after reaction with all LGL weights had complied with both standards' requirement except with $1.0 \mathrm{~g}$ of LGL. The percentage of removal heavy metals by using all parameter weights of LGL such as arsenic, cadmium, chromium, iron, manganese and zinc were around 98.8 to $99.8 \%, 53.8$ to $88.5 \%$, 94.7 to $96.5 \%, 99.6$ to $100 \%, 34.6$ to $38.9 \%$ and 27.0 to $90.1 \%$, respectively.
\end{abstract}

Keywords: limestone, acid mine drainage, heavy metal

\footnotetext{
Abstrak

Dalam kajian ini, batu kapur bergred rendah (LGL) telah digunakan dalam rawatan saliran lombong berasid (AMD). Berdasarkan keputusan pendaflour sinar-X (XRF), kandungan mineral kalsium karbonat di dalam batu kapur yang digunakan adalah sekitar $80 \%$ yang boleh dianggap sebagai LGL. pH sampel AMD telah bertambah selepas bertindakbalas dengan semua parameter berat LGL pada setiap lima minit selang masa. Parameter berat LGL yang digunakan dalam eksperimen adalah 1.0, 2.0, 3.0, 4.0, 5.0 dan 6.0 g. Untuk setiap parameter berat LGL, selang masa yang digunakan adalah $0,5,10,15,20,25$ dan 30 minit. Nilai $\mathrm{pH}$ yang paling tinggi diperolehi adalah $6.44 \pm 0.00$ dengan menggunakan $6.0 \mathrm{~g}$ LGL pada selang masa 30 minit. Nilai $\mathrm{pH}$ yang paling sesuai telah dipilih adalah $6.11 \pm 0.00$ dengan menggunakan $5.0 \mathrm{~g}$ LGL pada selang masa 20 minit kerana parameter ini adalah kurang kos untuk mematuhi Piawai A dan B berbanding parameter yang lain. Kandungan logam berat seperti arsenik, kadmium, kromium, besi, mangan dan zink telah berkurangan selepas bertindakbalas dengan semua berat LGL. Kandungan arsenik dalam sampel-sampel AMD selepas bertindakbalas dengan semua berat LGL telah dipatuhi dengan kehendak kedua-dua standard kecuali dengan menggunakan $1.0 \mathrm{~g}$ LGL. Peratusan penyingkiran logam berat dengan menggunakan semua parameter berat LGL seperti arsenik, kadmium, besi, mangan dan zink masing-masing adalah sekitar 98.8 hingga $99.8 \%, 53.8$ hingga $88.5 \%$, 94.7 hingga $96.5 \%, 99.6$ hingga $100 \%, 34.6$ hingga $38.9 \%$ and 27.0 hingga $90.1 \%$.
} 
Kata kunci: batu kapur, saliran lombong berasid, logam berat

\section{Introduction}

Limestone is a versatile material that can be used in many industries such as paper making, glass, food, plastics, paint, rubber, etc. [1, 2]. Limestone is a sedimentary rock with chemical formula $\mathrm{CaCO}_{3}[3]$ and $4 \%$ of the earth crust contains carbonate mineral that consists limestone, chalk and biominerals [4]. Limestone also can be used as a neutralization agent in treating acidic water especially in treating AMD [5]. Other materials that can be used to treat AMD are organic material [6], carbide lime [7], hydrated lime [8], quicklime [9], etc. In this study, low grade limestone was used in treating AMD. Limestone with the content of calcium carbonate mineral less than $94 \%$ can be classified as LGL [10]. The objective of this study is to show that LGL can be used as a material in treating AMD.

AMD is a global environmental problem caused by oxidation of sulphide minerals [11] such as pyrite, marcasite, arsenopyrite, sphalerite, chalcocite, etc. with the presence of water and sulphate oxidizing bacteria (SOB). AMD occurs can be shown in equations 1 to 3 [12].

$$
\begin{aligned}
& \mathrm{FeS}_{2}+7 \mathrm{O}_{2}+2 \mathrm{H}_{2} \mathrm{O} \longrightarrow 2 \mathrm{FeSO}_{4}+2 \mathrm{H}_{2} \mathrm{SO}_{4} \\
& 4 \mathrm{FeSO}_{4}+\mathrm{O}_{2}+2 \mathrm{H}_{2} \mathrm{SO}_{4} \longrightarrow 2 \mathrm{Fe}_{2}\left(\mathrm{SO}_{4}\right)_{3}+2 \mathrm{H}_{2} \mathrm{O} \\
& 7 \mathrm{Fe}_{2}\left(\mathrm{SO}_{4}\right)_{3}+\mathrm{FeS}_{2}+8 \mathrm{H}_{2} \mathrm{O} \longrightarrow 15 \mathrm{FeSO}_{4}+8 \mathrm{H}_{2} \mathrm{SO}_{4}
\end{aligned}
$$

AMD can be defined as acidic water in which its $\mathrm{pH}$ is less than 5, contains high concentration of sulphate and heavy metals such as arsenic, copper, lead, nickel, zinc, etc.

\section{Study area}

\section{Materials and Methods}

The study is focussed on the AMD problem that occurred in a tin tailing pond. The tin tailing pond is in a tin mine located in northern Perak. The tin tailing pond is a recycled pond which involves the activities related to tin ores.

\section{Materials}

In this study, LGL was used as neutralization agent and obtained from Pengkalan Hulu, Perak. AMD sample was collected from tin tailing pond also located in Pengkalan Hulu, Perak.

\section{Instrumentation}

Elemental analyses for LGL sample were determined by X-ray fluorescence using Shimadzu XRF-1700 sequential X-ray fluorescence spectrometer. The $\mathrm{pH}$ were measured using a Mettler Toledo Ross FE $20 \mathrm{pH}$ meter. The metal ions concentrations of the AMD samples were analysed by Perkin Elmer Optima DV 5300 ICP-OES.

\section{Methods}

Six experiments were carried out with different weights of low grade limestone used 1, 2, 3, 4, 5 and $6 \mathrm{~g}$, respectively. The different weights of limestone were added into individual $1 \mathrm{~L}$ beakers that contained $500 \mathrm{~mL}$ AMD samples. The AMD samples with different limestone weights were stirred at $500 \mathrm{rpm}$ by using overhead mechanical stirrer. During the stirring process, $\mathrm{pH}$ values of the solutions were recorded at interval times of $0,5,15$, 20, 25 and 30 minutes. The AMD samples were analysed by using ICP-OES for heavy metals content before and after reaction. Figure 1 shows the jar test of LGL reacted with AMD and Figure 2 shows the LGL samples before and after reaction with AMD. 

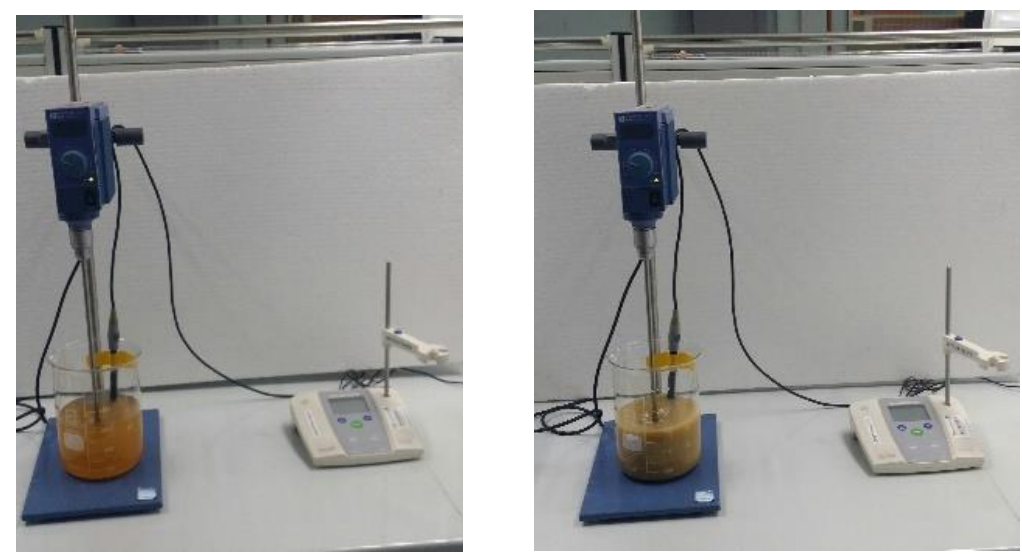

Figure 1. Jar test of AMD reacted with LGL

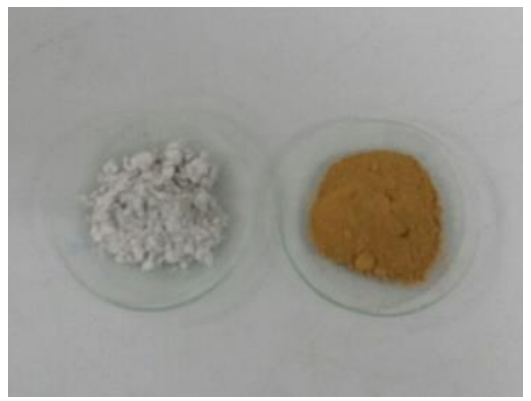

Figure 2. LGL before and after reaction with AMD sample

\section{Results and Discussion}

XRF result in Table 1 shows that the limestone used in this study was low grade because the content of calcium oxide obtained was $44 \%$ as shown in Table 1 . The percentage of calcium carbonate calculated was around $80 \%$ which indicates that it is a low grade limestone [3].

Table 1. X-ray fluorescent analysis result

\begin{tabular}{lc}
\hline Element Oxide & Result (\%) \\
\hline $\mathrm{Fe}_{2} \mathrm{O}_{3}$ & 0.48 \\
$\mathrm{MnO}$ & 0.11 \\
$\mathrm{TiO}_{2}$ & 0.20 \\
$\mathrm{CaO}$ & 44.15 \\
$\mathrm{~K}_{2} \mathrm{O}$ & 1.08 \\
$\mathrm{SiO}_{2}$ & 19.24 \\
$\mathrm{Al}_{2} \mathrm{O}_{3}$ & 3.28 \\
$\mathrm{MgO}^{\mathrm{Na}}$ & 0.89 \\
\hline
\end{tabular}


Table 2 shows the $\mathrm{pH}$ values of AMD samples before and after reaction with LGL as neutralisation agent. The initial $\mathrm{pH}$ of AMD samples was 2.47 . The highest $\mathrm{pH}$ obtained was $6.44 \pm 0.00$ by using $6.0 \mathrm{~g}$ of LGL at interval time 30 minutes. However, the optimal parameters selected was $5.0 \mathrm{~g}$ of LGL with retention time of 20 minutes which resulted in $\mathrm{pH}$ value of $6.11 \pm 0.00$. These parameters were chosen because it complied with Standards A and B of Environmental Quality Act 1974 which stated that the $\mathrm{pH}$ value for Standards A and B are 6.0 and 5.5 [13], respectively. Standard A refers to the discharge of effluent is upstream from catchment area and Standard B refers to the discharge of effluent is downstream from catchment area. Furthermore, the selected parameters will cost less in order to reach pH 6 compared to the other parameters. The reaction between LGL and AMD sample is shown in equation 4. $\mathrm{pH}$ value increase with the increasing of time caused to a lot of calcite $\left(\mathrm{CaCO}_{3}\right)$ dissolved in $\mathrm{AMD}$ sample. The reaction between LGL with AMD produced calcium ion $\left(\mathrm{Ca}^{2+}\right)$ and carbonic acid $\left(\mathrm{HCO}_{3}{ }^{-}\right)$. Carbonic acid further reacted with hydrogen ion $\left(\mathrm{H}^{+}\right)$to produce water and carbon dioxide gas. As a result, the use of $\mathrm{H}^{+}$can increase $\mathrm{pH}$ in AMD sample after the reaction [14].

$$
\mathrm{CaCO}_{3}+\mathrm{H}^{+} \longrightarrow \mathrm{Ca}^{2+}+\mathrm{HCO}_{3}^{-}
$$

Table 2. $\mathrm{pH}$ of AMD sample before and after reaction with six different weights of LGL

\begin{tabular}{lcll}
\hline $\begin{array}{l}\text { Weight of } \\
\text { LGL }(\mathbf{g})\end{array}$ & $\begin{array}{c}\text { Interval Time } \\
\text { (minutes) }\end{array}$ & \multicolumn{2}{c}{ pH } \\
\cline { 3 - 4 } 1.0 & 5 & $2.47 \pm 0.00$ & $3.84 \pm 0.00$ \\
& 10 & $2.47 \pm 0.00$ & $4.00 \pm 0.00$ \\
& 15 & $2.47 \pm 0.00$ & $4.07 \pm 0.00$ \\
20 & $2.47 \pm 0.01$ & $4.12 \pm 0.00$ \\
& 25 & $2.47 \pm 0.01$ & $4.15 \pm 0.00$ \\
& 30 & $2.47 \pm 0.01$ & $4.18 \pm 0.01$ \\
& 5 & $2.47 \pm 0.00$ & $4.35 \pm 0.01$ \\
& 10 & $2.47 \pm 0.00$ & $4.72 \pm 0.01$ \\
& 15 & $2.47 \pm 0.00$ & $4.98 \pm 0.00$ \\
& 20 & $2.47 \pm 0.01$ & $5.16 \pm 0.00$ \\
& 25 & $2.47 \pm 0.01$ & $5.43 \pm 0.01$ \\
3.0 & 30 & $2.47 \pm 0.01$ & $5.50 \pm 0.00$ \\
& 5 & $2.47 \pm 0.00$ & $4.90 \pm 0.01$ \\
& 10 & $2.47 \pm 0.00$ & $5.27 \pm 0.01$ \\
& 15 & $2.47 \pm 0.00$ & $5.54 \pm 0.00$ \\
& 20 & $2.47 \pm 0.01$ & $5.75 \pm 0.00$ \\
& 25 & $2.47 \pm 0.01$ & $5.92 \pm 0.01$ \\
& 30 & $2.47 \pm 0.01$ & $6.04 \pm 0.01$ \\
& 5 & $2.47 \pm 0.00$ & $5.09 \pm 0.00$ \\
& 10 & $2.47 \pm 0.00$ & $5.52 \pm 0.01$ \\
& 15 & $2.47 \pm 0.00$ & $5.79 \pm 0.01$ \\
& 20 & $2.47 \pm 0.01$ & $5.99 \pm 0.00$ \\
& 25 & $2.47 \pm 0.01$ & $6.13 \pm 0.01$ \\
& 30 & $2.47 \pm 0.01$ & $6.24 \pm 0.01$ \\
\hline
\end{tabular}


Table 2 (cont'd). pH of AMD sample before and after reaction with six different weights of LGL

\begin{tabular}{lccr}
\hline \multirow{2}{*}{$\begin{array}{l}\text { Weight of } \\
\text { LGL }(\mathbf{g})\end{array}$} & $\begin{array}{c}\text { Interval Time } \\
\text { (minutes) }\end{array}$ & \multicolumn{2}{c}{ pH } \\
\cline { 3 - 4 } & 5 & $2.47 \pm 0.00$ & $5.27 \pm 0.00$ \\
5.0 & 10 & $2.47 \pm 0.00$ & $5.65 \pm 0.01$ \\
& 15 & $2.47 \pm 0.00$ & $5.92 \pm 0.01$ \\
& 20 & $2.47 \pm 0.01$ & $6.11 \pm 0.00$ \\
& 25 & $2.47 \pm 0.01$ & $6.23 \pm 0.01$ \\
& 30 & $2.47 \pm 0.01$ & $6.33 \pm 0.01$ \\
& 5 & $2.47 \pm 0.00$ & $5.36 \pm 0.00$ \\
6.0 & 10 & $2.47 \pm 0.00$ & $5.75 \pm 0.01$ \\
& 15 & $2.47 \pm 0.00$ & $6.04 \pm 0.01$ \\
& 20 & $2.47 \pm 0.01$ & $6.23 \pm 0.00$ \\
& 25 & $2.47 \pm 0.01$ & $6.34 \pm 0.00$ \\
& 30 & $2.47 \pm 0.01$ & $6.44 \pm 0.00$ \\
\hline
\end{tabular}

Table 3 shows the heavy metals content in AMD samples before and after reaction with LGL. The results show that the content of heavy metals in AMD samples such as arsenic, cadmium, iron, chromium, manganese and zinc decreased after treated with LGL. Iron and chromium can be effectively treated by using LGL because the result show that in all AMD samples, the percentage of iron and chromium removal were more than $95 \%$. Their final concentrations complied with Standards A and B, iron are $1.0 \mathrm{mg} / \mathrm{L}$ and $5.0 \mathrm{mg} / \mathrm{L}$, whereas for chromium (III) are $0.20 \mathrm{mg} / \mathrm{L}$ and $1.0 \mathrm{mg} / \mathrm{L}$, respectively. For chromium (VI), Standards A and B is $0.05 \mathrm{mg} / \mathrm{L}$. The concentration of arsenic obtained after reaction complied with both standards except with $1.0 \mathrm{~g}$ of LGL that did not reach pH value 5 . The optimum of $\mathrm{pH}$ for arsenic removal is around 5 [15]. Standards A and B for arsenic are $0.05 \mathrm{mg} / \mathrm{L}$ and 0.10 $\mathrm{mg} / \mathrm{L}$, respectively. For zinc, its concentration complied with both standards after reaction with 4.0, 5.0 and $6.0 \mathrm{~g}$ of LGL, respectively. Standards A and B for zinc is $2.0 \mathrm{mg} / \mathrm{L}$. The concentrations of manganese and cadmium obtained after reaction in all parameters did not comply with both standards because manganese and cadmium can only be precipitated at $\mathrm{pH}$ around 10 and 11, respectively. Other techniques such as adsorption and oxidation are suitable to be used in treating manganese and cadmium. The reaction between AMD samples and LGL produced precipitation. Precipitation is one of the separation techniques to reduce heavy metals content in AMD samples. Heavy metals such as iron or zinc can be precipitated as carbonate or hydroxide metals as shown in Equations 5 and 6 , respectively [14].

$$
\begin{aligned}
& \mathrm{Fe}^{2+}+\mathrm{HCO}_{3}^{-} \longrightarrow \mathrm{FeCO}_{3}+\mathrm{H}^{+} \\
& \mathrm{Zn}^{2+}+2 \mathrm{H}_{2} \mathrm{O} \longrightarrow \mathrm{Zn}(\mathrm{OH})_{2}+2 \mathrm{H}^{+}
\end{aligned}
$$

Table 3. Heavy metals content in AMD samples before and after reaction with LGL

\begin{tabular}{llccc}
\hline $\begin{array}{l}\text { LGL Weight } \\
(\mathrm{g})\end{array}$ & Element & $\begin{array}{c}\text { Before Reaction } \\
(\mathbf{m g} / \mathbf{L})\end{array}$ & $\begin{array}{c}\text { After Reaction } \\
(\mathbf{m g} / \mathbf{L})\end{array}$ & $\begin{array}{c}\text { Percentage } \\
\text { Removal of } \\
\text { Heavy Metals }\end{array}$ \\
\hline 1.0 & & $6.44 \pm 0.34$ & $0.08 \pm 0.00$ & 98.8 \\
& $\mathrm{As}$ & $0.26 \pm 0.01$ & $0.12 \pm 0.00$ & 53.8 \\
& $\mathrm{Cd}$ & $317.27 \pm 13.41$ & $1.41 \pm 0.02$ & 99.6 \\
& $\mathrm{Fe}$ & $0.57 \pm 0.02$ & $0.03 \pm 0.00$ & 94.7 \\
& $\mathrm{Cr}$ & $61.63 \pm 2.65$ & $40.29 \pm 0.22$ & 34.6 \\
& $\mathrm{Mn}$ & $11.49 \pm 0.45$ & $8.39 \pm 0.05$ & 27.0 \\
\hline
\end{tabular}


Anuar et al: THE USE OF LOW GRADE LIMESTONE IN ACID MINE DRAINAGE TREATMENT

Table 3 (cont'd). Heavy metals content in AMD samples before and after reaction with LGL

\begin{tabular}{|c|c|c|c|c|}
\hline $\begin{array}{l}\text { LGL Weight } \\
\text { (g) }\end{array}$ & Element & $\begin{array}{l}\text { Before Reaction } \\
(\mathrm{mg} / \mathrm{L})\end{array}$ & $\begin{array}{c}\text { After Reaction } \\
(\mathrm{mg} / \mathrm{L})\end{array}$ & $\begin{array}{c}\text { Percentage } \\
\text { Removal of } \\
\text { Heavy Metals }\end{array}$ \\
\hline \multirow[t]{6}{*}{2.0} & As & $6.44 \pm 0.34$ & $0.03 \pm 0.00$ & 99.5 \\
\hline & $\mathrm{Cd}$ & $0.26 \pm 0.01$ & $0.11 \pm 0.00$ & 57.9 \\
\hline & $\mathrm{Fe}$ & $317.27 \pm 13.41$ & $0.32 \pm 0.00$ & 99.9 \\
\hline & $\mathrm{Cr}$ & $0.57 \pm 0.02$ & $0.02 \pm 0.00$ & 96.5 \\
\hline & $\mathrm{Mn}$ & $61.63 \pm 2.65$ & $40.16 \pm 0.30$ & 34.8 \\
\hline & $\mathrm{Zn}$ & $11.49 \pm 0.45$ & $6.30 \pm 0.05$ & 45.2 \\
\hline \multirow[t]{6}{*}{3.0} & As & $6.44 \pm 0.34$ & $0.01 \pm 0.00$ & 99.8 \\
\hline & $\mathrm{Cd}$ & $0.26 \pm 0.01$ & $0.07 \pm 0.00$ & 73.1 \\
\hline & $\mathrm{Fe}$ & $317.27 \pm 13.41$ & 0 & 100 \\
\hline & $\mathrm{Cr}$ & $0.57 \pm 0.02$ & $0.02 \pm 0.01$ & 96.5 \\
\hline & $\mathrm{Mn}$ & $61.63 \pm 2.65$ & $39.07 \pm 0.18$ & 36.6 \\
\hline & $\mathrm{Zn}$ & $11.49 \pm 0.45$ & $2.43 \pm 0.01$ & 78.6 \\
\hline \multirow[t]{6}{*}{4.0} & As & $6.44 \pm 0.34$ & $0.01 \pm 0.00$ & 99.8 \\
\hline & $\mathrm{Cd}$ & $0.26 \pm 0.01$ & $0.07 \pm 0.03$ & 73.1 \\
\hline & $\mathrm{Fe}$ & $317.27 \pm 13.41$ & 0 & 100 \\
\hline & $\mathrm{Cr}$ & $0.57 \pm 0.02$ & $0.02 \pm 0.00$ & 96.5 \\
\hline & $\mathrm{Mn}$ & $61.63 \pm 2.65$ & $38.26 \pm 0.34$ & 37.9 \\
\hline & $\mathrm{Zn}$ & $11.49 \pm 0.45$ & $1.69 \pm 0.03$ & 85.3 \\
\hline \multirow[t]{6}{*}{5.0} & As & $6.44 \pm 0.34$ & $0.01 \pm 0.00$ & 99.8 \\
\hline & $\mathrm{Cd}$ & $0.26 \pm 0.01$ & $0.03 \pm 0.00$ & 88.5 \\
\hline & $\mathrm{Fe}$ & $317.27 \pm 13.41$ & 0 & 100 \\
\hline & $\mathrm{Cr}$ & $0.57 \pm 0.02$ & $0.02 \pm 0.00$ & 96.5 \\
\hline & $\mathrm{Mn}$ & $61.63 \pm 2.65$ & $37.48 \pm 0.16$ & 39.2 \\
\hline & $\mathrm{Zn}$ & $11.49 \pm 0.45$ & $1.14 \pm 0.01$ & 90.1 \\
\hline \multirow[t]{6}{*}{6.0} & As & $6.44 \pm 0.34$ & $0.01 \pm 0.00$ & 99.8 \\
\hline & $\mathrm{Cd}$ & $0.26 \pm 0.01$ & $0.03 \pm 0.00$ & 88.5 \\
\hline & $\mathrm{Fe}$ & $317.27 \pm 13.41$ & 0 & 100 \\
\hline & $\mathrm{Cr}$ & $0.57 \pm 0.02$ & $0.02 \pm 0.00$ & 96.5 \\
\hline & $\mathrm{Mn}$ & $61.63 \pm 2.65$ & $37.64 \pm 0.07$ & 38.9 \\
\hline & $\mathrm{Zn}$ & $11.49 \pm 0.45$ & $1.14 \pm 0.01$ & 90.1 \\
\hline
\end{tabular}

\section{Conclusion}

LGL is capable to treat AMD by increasing the $\mathrm{pH}$ that complies with Standards A and B. The best $\mathrm{pH}$ value chosen was $6.11 \pm 0.00$ by using $5.0 \mathrm{~g}$ of LGL at interval time $20 \mathrm{~min}$. LGL is also suitable to be used in reducing heavy metals content in AMD such as arsenic, chromium and zinc by precipitation process. LGL is not suitable to be used for reducing manganese and cadmium content in AMD. More alkaline materials such as hydrated lime, quicklime, 
sodium hydroxide and so on are suitable to treat these heavy metals. Manganese and cadmium can be precipitated as hydroxide metals at $\mathrm{pH} 10$ [16] and pH range 10.5 to 11 [17], respectively.

\section{Acknowledgement}

The authors acknowledge the support of the Mineral Research Centre and the Chemistry Department, Faculty of Science, Universiti Teknologi Malaysia. Appreciation goes to the Director of Mineral Research Centre, Md Muzayin Alimon, Head of Rock Based Technology Section, Dr. Rohaya Othman, Head of Mineral Processing, Dr. Nazwin Ahmad and to Ex-Head of Rock Based Technology Section, Nasharuddin Isa, Mineral Research Centre staff especially to staff of Rock Based Technology Section, staff of Mining and Quarry Section and staff of Mineral Processing Technology Section.

\section{References}

1. Kirboga, S. and Oner, M. (2013). Application of experimental design for the precipitation of calcium carbonate in the presence of biopolymer. Powder Technology, 249: 95-104.

2. Othman, A., Isa, N. and Othman, R. (2015). Preparation of precipitated calcium carbonate using additive and without additive. Jurnal Teknologi, 77(3): 49-53.

3. Erdogan, N. and Eken, H.A. (2015). Precipitated calcium carbonate production, synthesis and properties. Physicochemical Problems of Mineral Processing, 2: 79-84.

4. Shirsath, S. R., Sonawane, S. H., Saini, D. R. and Pandit, A. B. (2015). Continuous precipitation of calcium carbonate using sonochemical reactor. Ultrasonics Sonochemistry, 24: 132-139.

5. Muhammad, S. N., Mohd Kusin, F., Md Zahar, M. S., Halimoon, N. and Mohamat Yusuf, F. (2015). Passive treatment of acid mine drainage using mixed substrates: Batch experiments. Procedia Environmental Sciences, 30: 157-161.

6. Othman, A., Sulaiman, A. and Sulaiman, S. K. (2015). The study on the effectiveness of organic material in acid mine drainage treatment. Jurnal Teknologi, 77(2): 79-84.

7. Othman, A., Sulaiman, A. and Sulaiman, S.K. (2017). Carbide lime in acid mine drainage treatment. Journal of Water Process Engineering, 15: 31-36.

8. Othman, A., Sulaiman, A. and Sulaiman, S. K. (2017). The use of hydrated lime in acid mine drainage treatment. AIP Proceeding, 1847: 1-6.

9. Othman, A., Sulaiman, A. and Sulaiman, S. K. (2017). The use of quicklime in acid mine drainage treatment. Chemical Engineering Transaction, 56: 1585-1590.

10. Harrison, D. J. (1993). Industrial minerals laboratory manual; Limestone. Minerology and Petrology Group, British Geological Survey. Technical Report, WG/92/29: pp. 1-45.

11. Teng, W., Kuang, J., Luo, Z. and Shu, W. (2017). Microbial diversity and community assembly across environmental gradients in acid mine drainage. Minerals, 7(106): 1-10.

12. Ekolu, S. O., Diop, S., Azene, F. and Mkhize, N. (2016). Disintegration of concrete construction induced by acid mine drainage attack. Journal of the South African Institution of a Civil Engineering, 58(1): 34-42.

13. Environmental Quality Act 1974 (Act 127), Regulations, Rules \& Orders. (2015). International Law Book Services, Selangor.

14. Chowdhury, A. R., Sarkar, D. and Datta, R. (2015). Remediation of acid mine drainage-impacted water. Current Pollution Reports, 1: 131-141.

15. Nenov, V., Dimitrova, N., Dobrevsky, I. and Rands, D. G. (1992). Effective precipitation of arsenic from aqueous solution by iron(iii) sulfate. Clean - Soil Air Water, 20(1): 14-17.

16. Kursunoglu, S. and Kaya, M. (2014). Dissolution and precipitation of zinc and manganese obtained from spent zinc-carbon and alkaline battery powder. Physicochemical Problems of Mineral Processing, 50(1): 41-45.

17. Aube, B. and Zinck, J. (2003). Lime treatment of acid mine drainage in Canada. Brazil-Canada Seminar on Mine Rehabilitation, 1 - 3 December, Florianopolis, Brazil. 